\title{
Brightening of the global cloud field by nitric acid and the associated radiative forcing
}

\author{
R. Makkonen ${ }^{1, *}$, S. Romakkaniemi ${ }^{2}$, H. Kokkola ${ }^{3}$, P. Stier ${ }^{4}$, P. Räisänen ${ }^{5}$, S. Rast ${ }^{6}$, J. Feichter ${ }^{6}$, M. Kulmala ${ }^{1}$, and \\ A. Laaksonen ${ }^{2,5}$ \\ ${ }^{1}$ Department of Physics, P.O. Box 64, 00014 University of Helsinki, Finland \\ ${ }^{2}$ Department of Applied Physics, University of Eastern Finland, P.O. Box 1627, 70211 Kuopio, Finland \\ ${ }^{3}$ Finnish Meteorological Institute, Kuopio Unit, P.O. Box 1627, 70211, Kuopio, Finland \\ ${ }^{4}$ Atmospheric, Oceanic and Planetary Physics, Department of Physics, University of Oxford, Parks Road, Oxford, \\ OX1 3PU, UK \\ ${ }^{5}$ Finnish Meteorological Institute, P.O. Box 503, 00101, Helsinki, Finland \\ ${ }^{6}$ Max Planck Institute for Meteorology, Bundesstr. 53, 20146 Hamburg, Germany \\ *now at: Department of Geosciences, University of Oslo, P.O. Box 1047, 0316 Oslo, Norway
}

Correspondence to: R. Makkonen (risto.makkonen@helsinki.fi)

Received: 8 February 2012 - Published in Atmos. Chem. Phys. Discuss.: 17 February 2012

Revised: 2 August 2012 - Accepted: 14 August 2012 - Published: 22 August 2012

\begin{abstract}
Clouds cool Earth's climate by reflecting $20 \%$ of the incoming solar energy, while also trapping part of the outgoing radiation. The effect of human activities on clouds is poorly understood, but the present-day anthropogenic cooling via changes of cloud albedo and lifetime could be of the same order as warming from anthropogenic addition in $\mathrm{CO}_{2}$. Soluble trace gases can increase water condensation to particles, possibly leading to activation of smaller aerosols and more numerous cloud droplets. We have studied the effect of nitric acid on the aerosol indirect effect with the global aerosol-climate model ECHAM5.5-HAM2. Including the nitric acid effect in the model increases cloud droplet number concentrations globally by $7 \%$. The nitric acid contribution to the present-day cloud albedo effect was found to be $-0.32 \mathrm{~W} \mathrm{~m}^{-2}$ and to the total indirect effect $-0.46 \mathrm{~W} \mathrm{~m}^{-2}$. The contribution to the cloud albedo effect is shown to increase to $-0.37 \mathrm{~W} \mathrm{~m}^{-2}$ by the year 2100 , if considering only the reductions in available cloud condensation nuclei. Overall, the effect of nitric acid can play a large part in aerosol cooling during the following decades with decreasing $\mathrm{SO}_{2}$ emissions and increasing $\mathrm{NO}_{\mathrm{x}}$ and greenhouse gases.
\end{abstract}

\section{Introduction}

Throughout industrialization humankind has injected increasing amounts of greenhouse gases (GHGs) into the atmosphere and thereby induced anthropogenic global warming. However, there has been a simultaneous increase in emissions of counteracting agents: aerosols and their precursors (e.g. $\mathrm{SO}_{2}$ ). Aerosols alter radiative fluxes directly by scattering and absorbing radiation, and indirectly by acting as cloud condensation nuclei $(\mathrm{CCN})$ and altering cloud properties (Twomey, 1977; Albrecht, 1989; Small et al., 2009). The present-day anthropogenic aerosol forcing (direct and cloud albedo effect) ranging from -0.5 to $-2.2 \mathrm{~W} \mathrm{~m}^{-2}$ (Forster et al., 2007) acts to cool Earth's climate, partly masking the warming from e.g. increased $\mathrm{CO}_{2}$ concentration. The indirect aerosol effects $\left(-0.5\right.$ to $-1.9 \mathrm{~W} \mathrm{~m}^{-2}$ for the cloud albedo effect, -0.3 to $-1.4 \mathrm{~W} \mathrm{~m}^{-2}$ for the cloud lifetime effect (Lohmann and Feichter, 2005)) are dominating the anthropogenic aerosol forcing over the direct effect $\left(-0.50 \pm 0.40 \mathrm{~W} \mathrm{~m}^{-2}\right.$ (Forster et al., 2007)).

Anthropogenic $\mathrm{SO}_{2}$ emissions increased from $2 \mathrm{Tg}\left(\mathrm{SO}_{2}\right)$ in year 1850 to $130 \mathrm{Tg}\left(\mathrm{SO}_{2}\right)$ in 1970 's, but have already decreased about $20 \%$ from the peak value due to emission regulations (Smith et al., 2011). In China, $\mathrm{SO}_{2}$ emissions increased between 2000 and 2006 by $53 \%$, but have already 
shown a decreasing trend since 2006 (Lu et al., 2010). The reductions of $\mathrm{SO}_{2}$ emissions due to air pollution control measures can cut global emissions even by $90 \%$ until 2100 (van Vuuren et al., 2007) which, together with reductions in primary particle emissions, would lead to a substantially weaker aerosol cooling in the future (Andreae et al., 2005; Arneth et al., 2009; Makkonen et al., 2012).

The future scenarios of $\mathrm{NO}_{\mathrm{x}}$ emissions show generally either a stronger increase (Bauer et al., 2007; Adams et al., 2001) or a weaker decrease (Lamarque et al., 2011) than $\mathrm{SO}_{2}$ emissions. Nitrogen oxides are formed during fuel combustion at high temperature and pressure, main sources being traffic, power generation and industry. In the IPCC scenario IS92a, annual $\mathrm{NO}_{\mathrm{x}}$ emissions were estimated to increase substantially from $28 \mathrm{Tg}(\mathrm{N})$ (year 2000) to $72 \mathrm{Tg}(\mathrm{N})$ (year 2100). Later, the IPCC SRES scenarios showed a large spread in emission estimates for the year 2100 (28$151 \mathrm{Tg}(\mathrm{N}) \mathrm{yr}^{-1}$ in the $\mathrm{A} 1$ scenario family). All SRES scenarios expect an increase in $\mathrm{NO}_{\mathrm{x}}$ emissions for a few decades (until 2040-2050), following stabilization (A1 and B2 scenario families), decline (by $\mathrm{NO}_{\mathrm{x}}$ emission control technologies and alternatives for fossil-fuel) or continued increase until 2100 (fossil-fuel intensive and high-population scenarios). The $\mathrm{NO}_{\mathrm{x}}$ emission pathways for the next IPCC report emission scenario development (Lamarque et al., 2011) indicate a range from 16 (van Vuuren et al., 2007) to 26 (Riahi et al., 2007) $\operatorname{Tg}(\mathrm{N})$ for the year 2100 , corresponding to a $30-60 \%$ decrease in $\mathrm{NO}_{\mathrm{x}}$ emissions from present-day levels. However, the ratio of global $\mathrm{NO}_{\mathrm{x}} / \mathrm{SO}_{2}$ emissions is increasing throughout the 21st century (Lamarque et al., 2011).

Nitrogen oxides are precursors of nitric acid. With enough gas-phase ammonia available, ammonium nitrate can form and partition to the aerosol phase. Although the presentday aerosol load and direct forcing from nitrate aerosols is considerably smaller than from sulfate aerosols (Liao et al., 2004), the nitrate aerosols can play an important part in the future. Adams et al. (2001) estimated that the nitrate aerosol direct forcing forcing was only $20 \%$ of the sulfate aerosol forcing in the year 2000, but with the SRES A2 future emission scenario, the nitrate forcing could be $50 \%$ stronger than sulfate forcing in the year 2100. Bauer et al. (2007) reported an increase of nitrate forcing from -0.11 to $-0.14 \mathrm{~W} \mathrm{~m}^{-2}$ from present-day to the year 2030, although this was accompanied with an increase in sulfate forcing. In Chen et al. (2010), the sulfate burden decreased slightly from 2.87 to $2.74 \mathrm{Tg}$ between the years 2000 and 2100 , whereas the nitrate burden quadrupled from 0.67 to $2.88 \mathrm{Tg}$.

It has been suggested that the effects of nitrogen oxides on clouds could be increasingly important with declining $\mathrm{SO}_{2}$ emissions (Kulmala et al., 1995). Nitric acid can condense on aqueous aerosols at relative humidities (RH) close to and exceeding $100 \%$ (Kulmala et al., 1997; Laaksonen et al., 1998; Kokkola et al., 1993). During cloud formation, RH increases relatively rapidly, and as it exceeds $100 \%$, the largest aerosols start activating to cloud droplets. With still increasing $\mathrm{RH}$, smaller and smaller particles activate until condensation of water to already activated particles depletes water from the air, peak RH is reached, and further activation ceases, leaving still smaller particles unactivated. The activated fraction of the total aerosol can vary from less than $1 \%$ to close to $100 \%$, depending on ambient conditions, and the concentration, size distribution and composition of the aerosol itself. Nitric acid influences the activation process because its condensation onto an aerosol particle increases the particle's hygroscopic mass and enables the particle to activate at lower RH. Furthermore, the acid condenses more efficiently to smaller particles with higher surface-to-volume ratio, and as a result, a larger fraction of the aerosol is able to activate (?Xue and Feingold, 2004). Recent ambient observations from a polluted region in China (with $\mathrm{HNO}_{3}$ mixing ratios as high as $5 \mathrm{ppb}$ ) indicate that nitric acid contributes to persistent clouds which may activate even at RH's slightly below $100 \%$ (Ma et al., 2010), which is in agreement with the earlier theoretical calculations of Kulmala et al. (1997) and Laaksonen et al. (1998). Experimental evidence of the role of $\mathrm{HNO}_{3}$ in cloud drop formation has also been obtained by Henin et al. (2011).

Beyond nitric acid also other semi-volatile compounds affect the cloud droplet formation. It has been shown that the effect of nitric acid is enhanced by the co-condensation of ammonia, which as a base neutralizes the solution and thus condensation takes place at the lower relative humidity compared to nitric acid condensation alone (Hegg, 2000; Romakkaniemi et al., 2005a). With high enough concentrations and/or low temperatures the co-condensation leads to the formation of ammonium nitrate. However, as shown by Romakkaniemi et al. (2005b) it is difficult to estimate how much ammonia enhances activation as partitioning of ammonia and nitric acid between different sized particles is highly dependent on the air mass history. Also some organic compounds are semivolatile, and in the recent study it was shown that they also have a lot of potential to affect cloud droplet formation (Topping and McFiggans, 2012).

We study the effect of nitric acid condensation on cloud droplet activation with a global climate model, and show the importance of nitric acid on the present-day indirect forcing. We also explore how the effect can change with projected decreases in particle number concentrations.

\section{Methods}

\subsection{Global aerosol-climate model ECHAM5.5-HAM2}

We use the aerosol-climate model ECHAM5.5-HAM2 (Zhang et al., 2012) extended by a two-moment cloud microphysics scheme (Lohmann et al., 2007). The model horizontal resolution is T42, corresponding to approximately $2.8^{\circ}$ grid. We use 31 vertical levels, extending from the surface to $10 \mathrm{hPa}$. Aerosols are activated as cloud droplets with 
the scheme of Abdul-Razzak and Ghan (Abdul-Razzak and Ghan, 2000; Stier et al., 2012). The updraft velocity is calculated from the grid-mean vertical velocity, turbulent kinetic energy and convectively available potential energy. The aerosol microphysics model M7 (Vignati et al., 2004) considers the dominant aerosol compounds: dust, sea salt, black carbon, particulate organic matter and sulfate. Atmospheric new particle formation is modeled with a parameterization of binary water-sulphuric acid nucleation (Vehkamäki et al., 2002). The aerosol model does not include nitrate aerosols.

The effect of nitric acid is parameterized according to Romakkaniemi et al. (2005a), based on results from a detailed numerical air parcel model. The parameterization is applied after the calculation of activated fraction without nitric acid $\left(F_{0}\right)$. The parameterization calculates the activated fraction $\left(F_{\mathrm{x}}\right)$ with a certain nitric acid volume mixing ratio from the aerosol size distribution, gas phase nitric acid concentration, temperature, total pressure, updraft velocity and the activated fraction without nitric acid. The parameterization takes into account the kinetic limitations of nitric acid and water condensation, and the effect of existing aerosol solubility. The effect of nitric acid is considered only for two aerosol modes, soluble Aitken and accumulation modes. Over continents, the number concentration of coarse mode particles is relatively small. In marine conditions, coarse mode sea-salt particles decrease the effect of $\mathrm{HNO}_{3}$ on cloud droplet number concentrations (CDNC) (Romakkaniemi et al., 2005a). The amount of nitric acid in nucleation mode can be considered negligible in all conditions as particles are very small.

Natural emissions of sea salt (Schulz et al., 2004), dust (Tegen et al., 2002) and DMS (Kettle and Andreae, 2000) are calculated online, i.e. based on model meteorology. Both eruptive (Halmer et al., 2002) and non-eruptive (Andres and Kasgnoc, 1998) volcanic sulfur emissions are included. Emissions of biogenic volatile organic compounds are prescribed monthly averages according to Guenther et al. (1995). Present-day anthropogenic aerosol and precursor emissions are taken from AeroCom emission inventory for the year 2000 (Dentener et al., 2006). For the future simulation, we apply one scenario from the "Representative Concentration Pathways" (RCPs), which are used for the emission scenario development process of IPCC AR5 (Moss et al., 2010; Lamarque et al., 2011). The selected pathway is RCP 3-PD (van Vuuren et al., 2007), which is the most optimistic one regarding emissions of $\mathrm{SO}_{2}$, with an emission reduction of $90 \%$ until the year 2100. Makkonen et al. (2012) have shown that the emissions of RCP 3-PD lead to a strong decrease in aerosol concentrations and the total aerosol forcing. We will only apply the aerosol and precursor emissions from the RCP 3-PD pathway: the nitric acid concentrations are for the year 2000 in all simulations.

\subsection{Radiative forcing}

We use two separate methods to analyze the effect of nitric acid on cloud albedo forcing and on total indirect forcing. To obtain the effect on cloud albedo, we run the ECHAM5.5HAM2 model for $5 \mathrm{yr}$ without coupling nitric acid to cloud microphysics. Instead, at each timestep we first calculate the CDNC with the Abdul-Razzak and Ghan parameterization (Abdul-Razzak and Ghan, 2000). Then, we calculate the increase in CDNC due to nitric acid, and perform the radiation calculations twice, with and without nitric acid. The instantaneous change in radiative fluxes at top-of-atmosphere is diagnosed as cloud albedo forcing. Since the nitric acid is prescribed as monthly average 3-D-fields, the variation in the cloud albedo forcing is rather small, and a 5-yr model integration is sufficient.

For the total indirect effect, two separate simulations are needed. One control simulation is done without nitric acid included. A second simulation is carried out, where the nitric acid is allowed to change the actual CDNC used in cloud microphysics. The perturbation in CDNC can then lead to changes in e.g. cloud albedo, cloud lifetime and precipitation. The total indirect effect is analyzed as the difference in the top-of-atmosphere short-wave fluxes between the two simulations. Although the overall climate is constrained by prescribed sea-surface temperatures, the coupling of nitric acid and CDNC can alter cloud fields significantly. Hence, the two simulations are integrated for $20 \mathrm{yr}$ to reduce the effect of the climate model's internal variability. The latter method used to obtain the total indirect forcing is essentially equivalent to quasi-forcing or fixed-SST-forcing calculated as radiative flux perturbation (Rotstayn and Penner, 2001).

The analyzed flux perturbations correspond to changes in present-day cloud forcing when nitric acid is explicitly described in cloud activation. Since the used nitric acid fields also contain natural sources, the resulting change in radiative fluxes is not strictly the anthropogenic forcing. However, global anthropogenic $\mathrm{NO}_{\mathrm{x}}$ emissions are almost fivefold compared to emissions from natural sources (Delmas et al., 1997), and in areas with clouds most affected by nitric acid, the influence of anthropogenic $\mathrm{NO}_{\mathrm{x}}$ emissions is presumably even higher.

\section{$2.3 \quad$ Nitric acid}

The nitric acid concentration fields are prescribed monthly mean volume mixing ratios from the RETRO study calculated with the chemistry global circulation model ECHAM5_MOZ (Rast et al., 2012). The nitric acid fields are representative of the year 2000 . The chemistry in the ECHAM5_MOZ is based on MOZART2 (Horowitz et al., 2003). Nitrate aerosols are not included in ECHAM5_MOZ, hence the applied nitric acid concentration includes also the aerosol-phase nitrate. This leads to an overestimation of the nitric acid concentration, especially during nighttime. All 
Table 1. Acronyms and description of the experiments. In HNO3_DIAG_2000 and HNO3_DIAG_2100, the effect of $\mathrm{HNO}_{3}$ is diagnosed during simulation, and $\mathrm{HNO}_{3}$ does not affect modeled climate. In $\mathrm{HNO} 3$ FULL_2000, the coupling of $\mathrm{HNO}_{3}$, $\mathrm{CDNC}_{2}$ and modeled climate is implemented.

\begin{tabular}{ccccc}
\hline Experiment name & $\begin{array}{c}\text { Aerosol and } \\
\text { precursor emissions }\end{array}$ & $\begin{array}{c}\mathrm{HNO}_{3} \\
\text { concentrations }\end{array}$ & $\begin{array}{c}\text { Simulated } \\
\text { years }\end{array}$ & $\mathrm{HNO}_{3}$ effect \\
\hline HNO3_DIAG_2000 & AeroCom year 2000 & Year 2000 & 5 & Diagnostic \\
HNO3_DIAG_2100 & RCP 3-PD year 2100 & Year 2000 & 5 & Diagnostic \\
CTRL_2000 & AeroCom year 2000 & Year 2000 & 20 & Uncoupled \\
HNO3_2000 & AeroCom year 2000 & Year 2000 & 20 & Coupled \\
\hline
\end{tabular}

nitrate is assumed to be gas-phase nitric acid available for condensation, although in reality some of the nitric acid could already reside in the cloud phase due to earlier cloud cycle and would not enhance further activation. We do not apply any diurnal variation to the nitric acid concentration.

Although the ECHAM5_MOZ can capture the vertical distribution of nitric acid quantitatively well, there is a rather systematic overestimation of the concentrations. Overall bias, based on 15 different campaigns, is $74 \%$ at $500 \mathrm{hPa}$ and $124 \%$ at $900 \mathrm{hPa}$. The overestimation could be related to too high $\mathrm{NO}_{\mathrm{x}}$ emissions, too low wet deposition, or the lack of treatment of nitrate aerosol in ECHAM5_MOZ. The applied nitric acid fields are quantitatively similar to those in $\mathrm{Xu}$ and Penner (2012), with global average surface concentrations of 165 pptv and 174 pptv in this study and $\mathrm{Xu}$ and Penner (2012), respectively. Surface $\mathrm{HNO}_{3}$ concentrations over remote oceans are slightly higher in ECHAM5_MOZ, while $\mathrm{Xu}$ and Penner (2012) show generally higher concentrations over continents.

\subsection{Simulation setup}

The conducted experiments are shown in Table 1. In experiments HNO3_DIAG_2000 and HNO3_DIAG_2100 the effect of nitric acid on CDNC is only diagnosted, and nitric acid does not affect simulated climate. In HNO3_2000, the CDNC perturbations due to nitric acid will affect cloud properties and simulated climate, whereas in CTRL_2000, the effect of nitric acid is completely turned off.

\section{Results and discussion}

\subsection{Nitric acid effect on activation}

Figure 1 shows the distribution of activated fractions $F_{\mathrm{X}}$ and $F_{0}$ at 8 different heights between 100 and $2000 \mathrm{~m}$, taken from simulations without coupling of nitric acid and cloud microphysics (HNO3_DIAG_2000). The scatter plot is generated by correlating $F_{\mathrm{x}}$ with $F_{0}$ at each model grid point at a specific height. At low altitudes (100-200 m) the activated fraction $F_{0}$ without nitric acid effect can easily reach values over 0.3 , and Fig. 1 shows a large spread in the activated fraction $F_{\mathrm{x}}$ with nitric acid at these values. Nitric acid

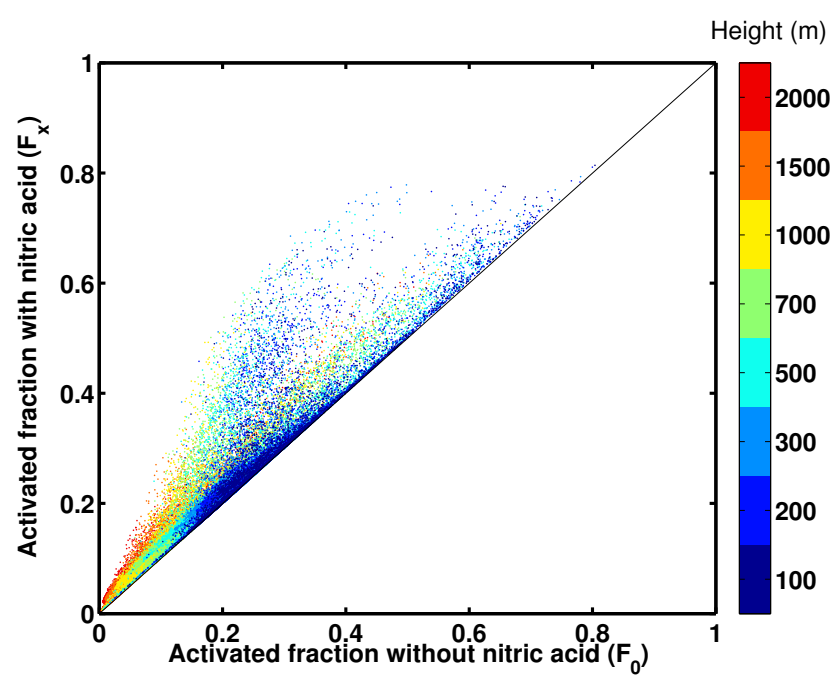

Fig. 1. Scatter plot of activated fraction with nitric acid $\left(F_{\mathrm{X}}\right)$ plotted against activated fraction without nitric acid $\left(F_{0}\right)$ at 8 different heights. The scatter plots are generated by plotting 5 -yr average activated fractions in each grid point against each other. The data is from simulations without coupling of nitric acid and cloud microphysics (experiment HNO3_DIAG_2000).

can not decrease the activated fraction at any point. The relative increase in activated fraction due to nitric acid increases monotonously with height, from about $10-20 \%$ below $1 \mathrm{~km}$ to $>50 \%$ above $3.5 \mathrm{~km}$.

The zonal distribution of CDNC increase due to nitric acid is shown in Fig. 2, calculated from experiments HNO3_2000 and CTRL_2000. The strongest effect is seen in the midtroposphere between $500-800 \mathrm{hPa}$ and between $30^{\circ} \mathrm{S}-60^{\circ} \mathrm{N}$, where nitric acid can increase CDNC by more than $10 \%$ in large areas. Figure 2 shows also the ratio of nitric acid mass versus Aitken and accumulation mode sulfate mass, indicating potential increase in nitric acid effect with height.

\subsection{Present-day forcing due to nitric acid}

Our simulations show a strong effect from the inclusion of nitric acid on total short-wave radiation fluxes at top-of-atmosphere: $-0.32 \pm 0.01 \mathrm{~W} \mathrm{~m}^{-2}$ for the cloud albedo effect (HNO3_DIAG_2000) and $-0.46 \pm 0.26 \mathrm{~W} \mathrm{~m}^{-2}$ 


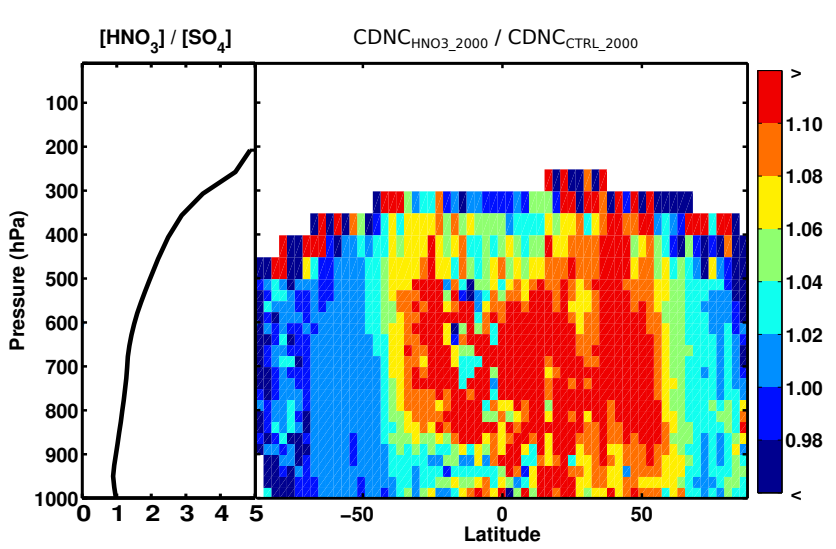

Fig. 2. Ratio of nitric acid mass vs. sulfate mass in Aitken and accumulation modes (left panel) and 20-yr zonal average ratio of CDNC between simulations with (HNO3_2000) and without (CTRL_2000) nitric acid (right panel).

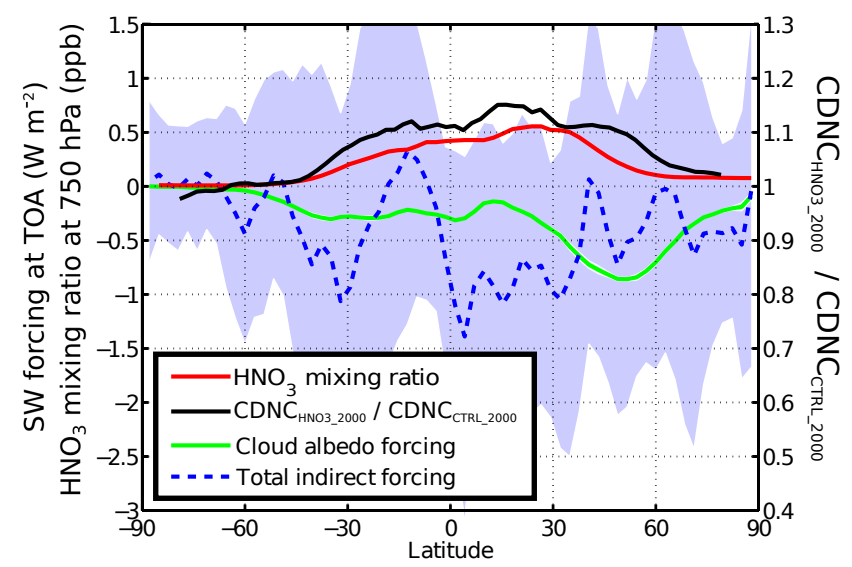

Fig. 3. Zonal average nitric acid mixing ratio at $750 \mathrm{hPa}(\mathrm{ppb})$, cloud albedo forcing $\left(\mathrm{W} \mathrm{m}^{-2}\right)$ (experiment HNO3_DIAG_2000) and total indirect forcing $\left(\mathrm{W} \mathrm{m}^{-2}\right)$ due to inclusion of nitric acid. The total indirect forcing is calculated as the difference in topof-atmosphere short-wave fluxes between experiments HNO3_2000 and CTRL_2000. Also shown is the ratio of CDNC at the $750 \mathrm{hPa}$ level between experiments HNO3_2000 and CTRL_2000. The blue shading corresponds to standard deviation of the total indirect forcing. The standard deviation is presented also for the cloud albedo forcing, but it is almost indistinguishable from the green line.

$\left(-0.42 \pm 0.28 \mathrm{~W} \mathrm{~m}^{-2}\right.$ when accounting for longwave radiation) for the total indirect effect (HNO3_2000), with the uncertainty range indicating the inter-annual standard deviation. The effect is rather large compared to the simulated anthropogenic indirect forcing without nitric acid, $-1.6 \mathrm{~W} \mathrm{~m}^{-2}$.

With the $\mathrm{NO}_{\mathrm{x}}$ sources mostly confined to the Northern Hemisphere, the cooling from nitric acid has a strong zonal pattern. Figure 3 shows the cloud albedo effect peaking between $20^{\circ} \mathrm{N}-80^{\circ} \mathrm{N}$, reaching a value of $-0.90 \mathrm{~W} \mathrm{~m}^{-2}$ around $50^{\circ} \mathrm{N}$. The hemisphere-mean effect of nitric acid on cloud albedo forcing is $-0.17 \mathrm{~W} \mathrm{~m}^{-2}$ for the Southern Hemisphere and $-0.43 \mathrm{~W} \mathrm{~m}^{-2}$ for the Northern Hemisphere. Similarly to the cloud albedo effect, the total indirect effect shows a strong contrast between Southern $\left(-0.20 \mathrm{~W} \mathrm{~m}^{-2}\right)$ and Northern $\left(-0.59 \mathrm{~W} \mathrm{~m}^{-2}\right)$ Hemisphere. The 5 -yr global averages of the total indirect forcing extracted from the 20yr simulation are $-0.38,-0.49,-0.38$ and $-0.58 \mathrm{~W} \mathrm{~m}^{-2}$, so they all exceed the cloud albedo forcing of $-0.32 \mathrm{~W} \mathrm{~m}^{-2}$. Figure 3 shows that the nitric acid induced perturbation to CDNC follows the nitric acid concentration, indicating that the fluctuations in total indirect effect are arising from changes in modeled cloud cover.

As shown in Fig. 4, there are differences between the spatial distributions of $\mathrm{HNO}_{3}$ concentration and the simulated cloud albedo forcing. In addition to the nitric acid concentration, the nitric acid effect on cloud droplet concentration depends on the aerosol distribution, temperature, updraft velocity and activated fraction. The annual average $\mathrm{HNO}_{3}$ mixing ratio at the $750 \mathrm{hPa}$ level (Figure 4a) reaches $>1 \mathrm{ppb}$ in polluted regions (middle Africa, India, China) and is mostly between $0.1-1 \mathrm{ppb}$ over continents. Although surface concentrations are even higher close to $\mathrm{NO}_{\mathrm{x}}$ sources (annual average several ppb), the $750 \mathrm{hPa}$ level shows clearly the transport of $\mathrm{HNO}_{3}$ over oceans. The transport of $\mathrm{HNO}_{3}$ has been observed from satellites, and $\mathrm{HNO}_{3}$ has been suggested as a reservoir of $\mathrm{NO}_{\mathrm{x}}$ (Wespes et al., 2007). In large parts of the North Atlantic, $\mathrm{HNO}_{3}$ levels are between 0.3$0.5 \mathrm{ppb}$. The outflow from Africa establishes even 0.5-1 ppb of $\mathrm{HNO}_{3}$ over the South Atlantic. The overall effect of $\mathrm{HNO}_{3}$ on cloud droplet number concentration is largest over continents, especially over polluted regions. The cloud albedo effect ranges from -1.5 to $-2 \mathrm{~W} \mathrm{~m}^{-2}$ over Eastern US, Europe, central Africa and Japan. The forcing is stronger than $-0.2 \mathrm{~W} \mathrm{~m}^{-2}$ over all continental regions except for northern Africa, Middle East and Greenland. At certain locations, even a high $\mathrm{HNO}_{3}$ concentration is not enough to produce a strong cooling: e.g. in India, the annual average $\mathrm{HNO}_{3}$ concentration of $1 \mathrm{ppb}$ or more leads to a forcing from only -0.2 to $-0.7 \mathrm{~W} \mathrm{~m}^{-2}$. The cooling over India is most prominent during summer months, when the simulated aerosol concentrations are lower than average. With high enough aerosol number concentrations, the amount of nitric acid partitioned in each particle, and subsequent effect on activation, is small (Nenes et al., 2002).

The cloud albedo forcing found here, $-0.32 \mathrm{~W} \mathrm{~m}^{-2}$, is slightly higher than the present-day indirect effect of $-0.23 \mathrm{~W} \mathrm{~m}^{-2}$ of total nitrate and ammonium found in $\mathrm{Xu}$ and Penner (2012). Although the results in $\mathrm{Xu}$ and Penner (2012) include the contribution of particulate nitrate, the indirect effect is mainly due to gaseous nitric acid. The spatial patterns of the cloud albedo forcing are very similar. $\mathrm{Xu}$ and Penner (2012) show stronger forcing in Australia, continental South-East Asia, southern US and continental outflow regions, whereas the forcing found in this study is stronger in Europe, around Japan, and middle Africa. The gas-phase 
(a) $\mathrm{HNO}_{3}$ mixing ratio at $750 \mathrm{hPa}$

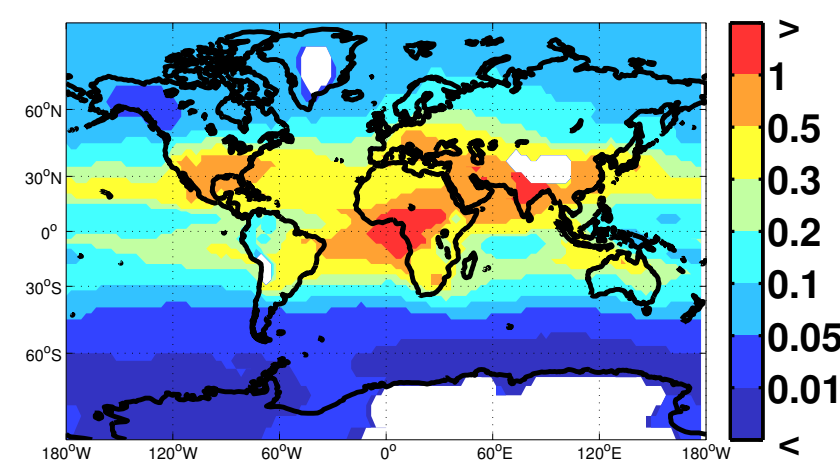

(c) Cloud albedo forcing (HNO3_DIAG_2000)

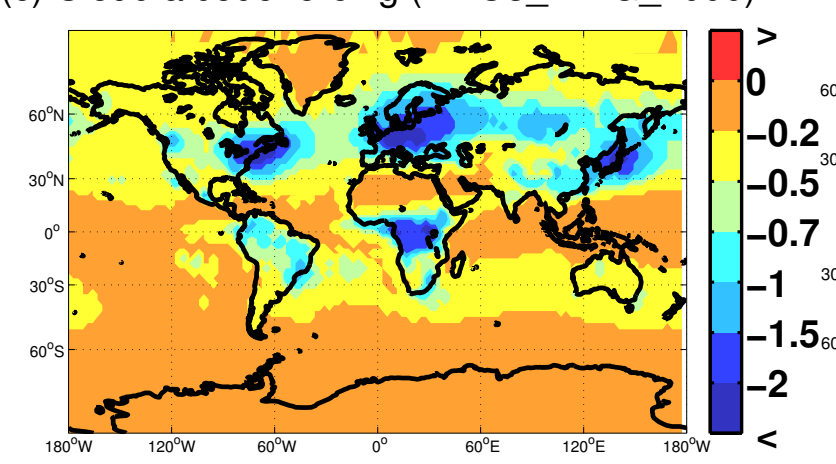

(b) $\operatorname{CCN}(0.2 \%)$ HNO3_DIAG_2000

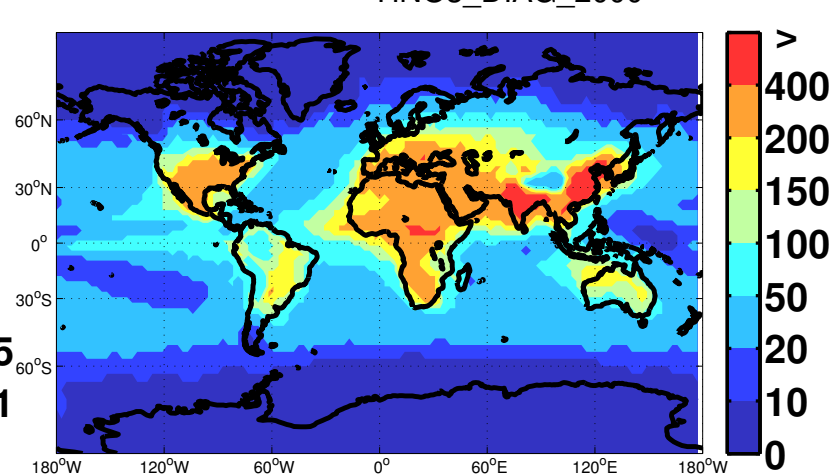

(d) Total indirect forcing

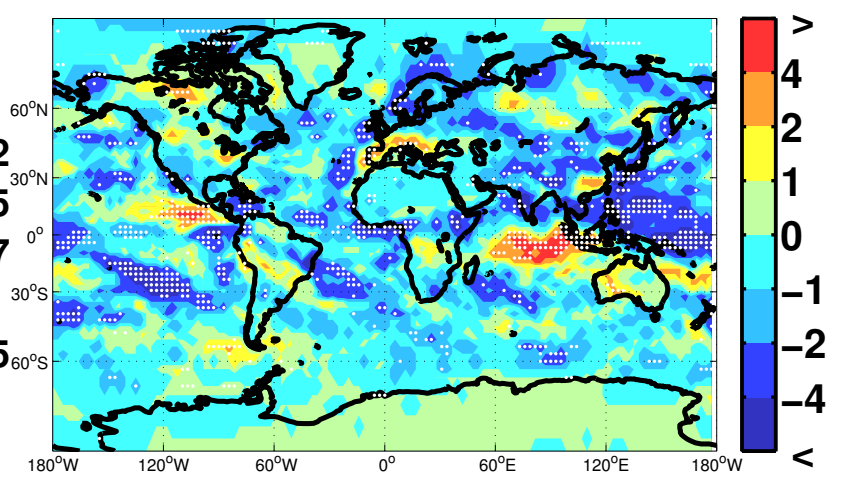

Fig. 4. (a) Annual average nitric acid mixing ratio at $750 \mathrm{hPa}(\mathrm{ppb})$, (b) surface-level $\mathrm{CCN}(0.2 \%)\left(\mathrm{cm}^{-3}\right)$ from experiment HNO3_DIAG_2000 (unperturbed by nitric acid), (c) cloud albedo forcing $\left(\mathrm{W} \mathrm{m}^{-2}\right.$ ) (experiment HNO3_DIAG_2000) and (d) total indirect forcing $\left(\mathrm{W} \mathrm{m}^{-2}\right)$ due to inclusion of nitric acid, calculated from experiments HNO3_2000 and CTRL_2000. The cloud albedo forcing is averaged over $5 \mathrm{yr}$, the total indirect forcing over $20 \mathrm{yr}$. White dots in (d) indicate statistical significance with $p<0.05$.

nitric acid fields used in Xu and Penner (2012) are very similar to those applied here, averaging in the surface layer of the model to 165 pptv and 174 pptv in this study and Xu and Penner (2012), respectively. The nitric acid concentrations over oceans in our study are slightly higher than those in $\mathrm{Xu}$ and Penner (2012).

The nitric acid inclusion leads to a global annual-mean increase of $7 \%$ in CDNC, which is a clear signal of the nitric acid effect and sufficient for a significant cloud albedo perturbation. The CDNC increase is in good agreement with $\mathrm{Xu}$ and Penner (2012), where CDNC increased by $2.4 \%$ due to particulate nitrate and $11.5 \%$ due to total nitrate (including nitric acid effect). The zonal averages in Fig. 3 show that this CDNC increase follows the nitric acid concentration. However, the zonal averages of the total indirect forcing (Fig. 3) and especially its horizontal distribution (Fig. 4d) differ substantially from the cloud albedo effect. Indeed, Fig. 4d shows that locally, the total indirect effect can be either stronger or weaker negative than the cloud albedo effect, and even positive at many locations. The areas with positive (strong negative) total indirect forcing generally correspond to reduced (increased) cloudiness. For the most part, the changes in the horizontal distribution of cloudiness (not shown) are statistically insignificant, that is, they are undistinguishable from the internal variability of the model's climate. Thus the small-scale patterns seen in Fig. $4 \mathrm{~d}$ are not robust. However, the nitric acid induced changes in global-mean low cloud fraction and middle cloud fraction $(0.38 \%$ and $0.40 \%$, respectively) are both significant at higher than $99.9 \%$ level of confidence. This is consistent with the global-mean total indirect effect being larger than the cloud albedo effect, and provides evidence that at least in this model, nitric acid acts to increase the average cloud lifetime.

\subsection{Effect of decreasing future aerosol concentration}

To study the impact of decreasing aerosol concentration on the effect of nitric acid, we show results from simulations with aerosol and precursor emissions of the year 2100 , but with present-day nitric acid concentrations. Low emissions of the RCP 3-PD pathway lead to a strong decrease in $\mathrm{CCN}(0.2 \%)$ concentration (Fig. 5a and b), except for high-latitude regions. In continental Northern hemisphere, the decrease in $\mathrm{CCN}(0.2 \%)$ concentration is generally over $50 \%$, while in South America, Africa and Australia the decrease is slightly smaller. More details on changing number 
(a) $\mathrm{CCN}(0.2 \%)_{\text {HNO3 DIAG } 2000}$

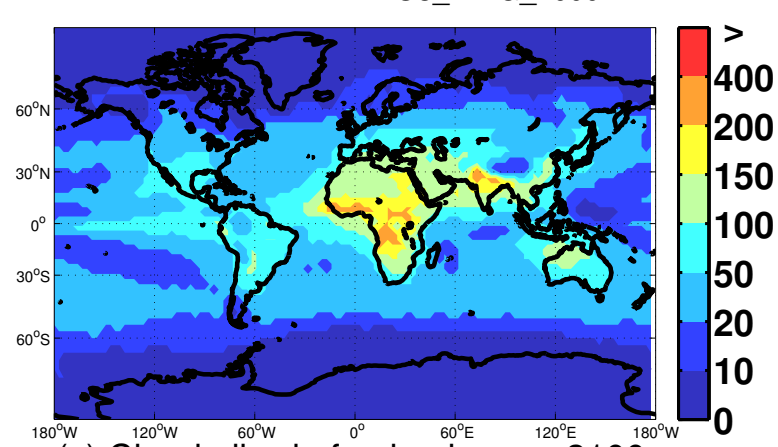

(c) Cloud albedo forcing in year 2100

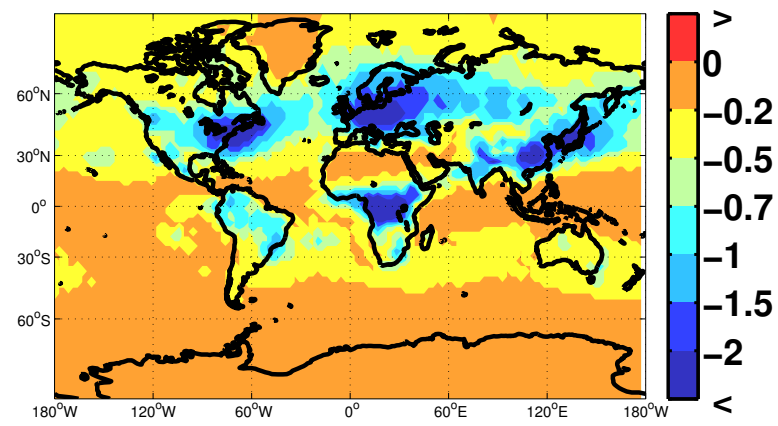

(b) $\mathrm{CCN}$ HNO3_DIAG_2100/ CCN ${ }_{\text {HNO3_DIAG_2000 }}$

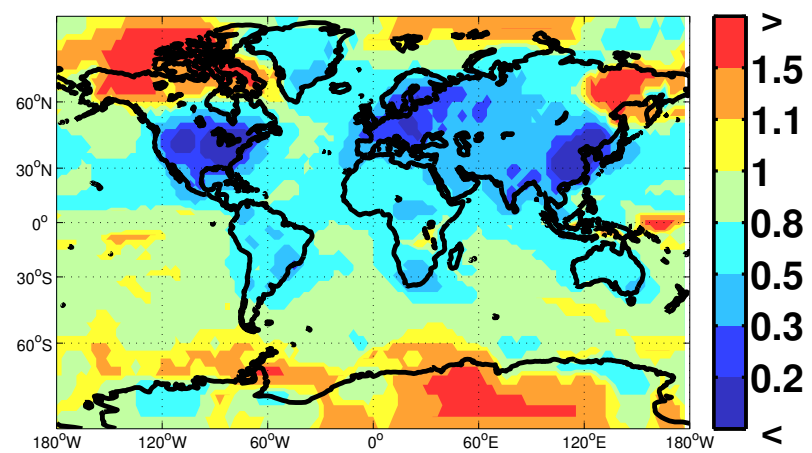

(d) Change in cloud albedo forcing (2100-2000)

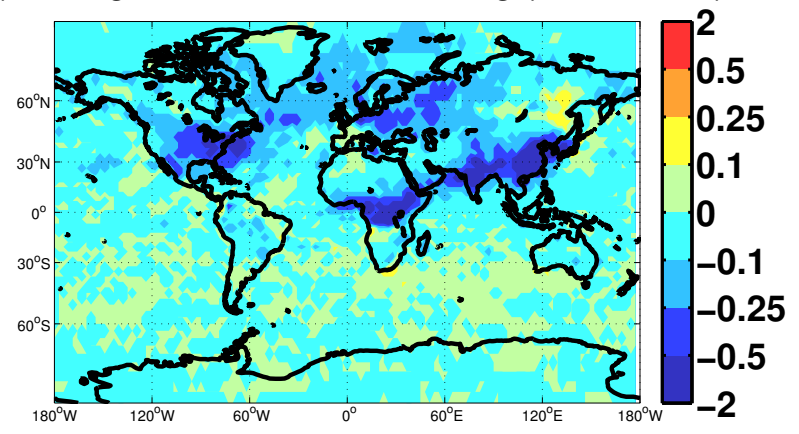

Fig. 5. (a) Surface-level CCN $(0.2 \%)\left(\mathrm{cm}^{-3}\right)$ in year 2100 (HNO3_DIAG_2100), (b) ratio of CCN(0.2\%) between years 2100 and 2000 (experiments HNO3_DIAG_2100 and HNO3_DIAG_2000), (c) cloud albedo forcing ( $\mathrm{W} \mathrm{m}^{-2}$ ) due to nitric acid in year 2100 (experiment HNO3_DIAG_2100), and (d) the change in cloud albedo forcing due to nitric acid ( $\mathrm{W} \mathrm{m}^{-2}$ ) between years 2000 and 2100 (negative values indicate more cooling due to nitric acid in year 2100). The change in (d) is calculated as a difference of nitric acid cloud albedo forcing in experiments HNO3_DIAG_2100 and HNO3_DIAG_2000.

concentration under RCP 3-PD can be found in Makkonen et al. (2012). Note that the shown CCN concentrations are unperturbed by nitric acid.

The change in nitric acid cloud albedo forcing between years 2000 and 2100 shown in Fig. 5 is clearly connected to the change in $\mathrm{CCN}(0.2 \%)$ concentration. The cloud albedo forcing due to nitric acid is intensified by more than $0.25 \mathrm{~W} \mathrm{~m}^{-2}$ in North America, Central Africa, India, China and Eastern Europe, when moving from year 2000 to 2100. These areas show a simultaneous decrease in $\mathrm{CCN}(0.2 \%)$ by more than $200\left(\mathrm{~cm}^{-3}\right)$ (a decrease of 50-80\%). Even though the simulated present-day cloud albedo forcing can reach high values even in rather polluted areas, the results indicate that cleaning the air from particulate pollutants intensifies the nitric acid effect. The resulting negative forcing could balance the loss in aerosol forcing. The present-day global average cloud albedo effect of $-0.32 \mathrm{~W} \mathrm{~m}^{-2}$ is increased to $-0.37 \mathrm{~W} \mathrm{~m}^{-2}$ in the year 2100 .

It should be noted that our future simulation only focused on the effect of decreasing number concentrations on the magnitude of the nitric acid effect. Also, the number concentrations are simulated with a model without nitrate aerosols, hence the anthropogenic emission changes stem only from $\mathrm{SO}_{2}, \mathrm{BC}$ and $\mathrm{OC}$. The applied nitric acid concen- tration is identical for years 2000 and 2100 , while the RCP $3-P D$ shows a $60 \%$ decrease in anthropogenic $\mathrm{NO}_{\mathrm{x}}$ emissions (Lamarque et al., 2011). RCP 3-PD also predicts a $70 \%$ increase in ammonia emissions, however the global ammonium aerosol burden is decreasing due to a decrease in $\mathrm{NO}_{\mathrm{x}}$ (Lamarque et al., 2011). To fully quantify the effect of nitric acid condensation in the future aerosol forcing requires simulations with coupled aerosol-chemistry models including nitrate aerosols.

\section{Conclusions}

We have presented global model simulations with explicit inclusion of the effect of nitric acid condensation on cloud droplet activation. The increased soluble material increases cloud droplet number concentrations significantly, leading to a $-0.32 \pm 0.01 \mathrm{~W} \mathrm{~m}^{-2}$ cloud albedo forcing and a total indirect forcing of $-0.46 \pm 0.26 \mathrm{~W} \mathrm{~m}^{-2}$ with present-day emissions. While the cloud albedo effect is spatially coupled to nitric acid concentrations, the total indirect forcing is dominated by changes in low and middle cloud cover. The spatial distribution of cloud cover changes can be very much model dependent, nonetheless the total indirect effect 
qualifies for an estimate for cloud effects beyond the cloud albedo effect.

We also showed that with decreasing aerosol number concentrations in the future, the effect of nitric acid could play a more important role. The applied future pathway with over $50 \%$ reductions in $\mathrm{CCN}$ concentrations led to a nitric acid cloud albedo forcing of $-0.37 \pm 0.01 \mathrm{~W} \mathrm{~m}^{-2}$ in year 2100 . While the simulation did not take into account changes in $\mathrm{NO}_{\mathrm{x}}$, nitrate aerosol or ammonia, it serves as indication on the effect of particle number reductions. Despite the benefits from added cooling, other environmental impacts (acid rain, ozone production) and health issues speak for reduction measures of $\mathrm{NO}_{\mathrm{x}}$ emissions. To account for the total effect of $\mathrm{NO}_{\mathrm{x}}$ on aerosols and clouds, one should also consider $\mathrm{NO}_{\mathrm{x}}$ as a source of ozone.

Acknowledgements. The financial support by the Academy of Finland Centre of Excellence program (project no. 1118615) and EU-project EUCAARI (European Integrated project on Aerosol Cloud Climate and Air Quality interactions, project no. 036833-2) is gratefully acknowledged. We thank the Finnish IT center for science (CSC) for technical support and computing time. M. Kulmala acknowledges support from the European Research Council Advanced Grant (no. 227463). S. Romakkaniemi has been supported by the strategic funding of the University of Eastern Finland. P. Räisänen acknowledges support from the Academy of Finland (project no. 127210). We are grateful to the two anonymous reviewers for their valuable comments and suggestions.

Edited by: C. Hoose

\section{References}

Abdul-Razzak, H. and Ghan, S. J.: A parameterization of aerosol activation - 2: Multiple aerosol types, J. Geophys. Res., 105, 6837-6844, 2000.

Adams, P., Seinfeld, J., Koch, D., Mickley, L., and Jacob, D.: General circulation model assessment of direct radiative forcing by the sulfate-nitrate-ammonium-water inorganic aerosol system, J. Geophys. Res., 106, 1097, doi:10.1029/2000JD900512, 2001.

Albrecht, B. A.: Aerosol, cloud microphysics, and fractional cloudiness, Science, 245, 1227-1230, 1989.

Andreae, M., Jones, C., and Cox, P.: Strong present-day cooling implies a hot future, Nature, 435, 1187-1190, 2005.

Andres, R. J. and Kasgnoc, A. D.: A time-averaged inventory of subaerial volcanic sulfur emissions, J. Geophys. Res. D: Atmos., 103, 25251-25261, doi:10.1029/98JD02091, 1998.

Arneth, A., Unger, N., Kulmala, M., and Andreae, M. O.: Clean the Air, Heat the Planet?, Science, 326, 672-673, doi:10.1126/science.1181568, 2009.

Bauer, S. E., Koch, D., Unger, N., Metzger, S. M., Shindell, D. T., and Streets, D. G.: Nitrate aerosols today and in 2030: a global simulation including aerosols and tropospheric ozone, Atmos. Chem. Phys., 7, 5043-5059, doi:10.5194/acp-7-5043-2007, 2007.
Chen, W.-T., Lee, Y., Adams, P., Nenes, A., and Seinfeld, J.: Will black carbon mitigation dampen aerosol indirect forcing?, Geophys. Res. Lett., 37, L09801, doi:10.1029/2010GL042886, 2010.

Delmas, R., Serça, D., and Jambert, C.: Global inventory of NOx sources, Nutr. Cycl. Agroecosys., 48, 51-60, doi:10.1023/A:1009793806086, 1997.

Dentener, F., Kinne, S., Bond, T., Boucher, O., Cofala, J., Generoso, S., Ginoux, P., Gong, S., Hoelzemann, J. J., Ito, A., Marelli, L., Penner, J. E., Putaud, J.-P., Textor, C., Schulz, M., van der Werf, G. R., and Wilson, J.: Emissions of primary aerosol and precursor gases in the years 2000 and 1750 prescribed data-sets for AeroCom, Atmos. Chem. Phys., 6, 4321-4344, doi:10.5194/acp-64321-2006, 2006.

Forster, P., Ramaswamy, V., Artaxo, P., Berntsen, T., Betts, R., Fahey, D. W., Haywood, J., Lean, J., Lowe, D. C., Myhre, G., Nganga, J., Prinn, R., Raga, G., Schulz, M., and Van Dorland, R.: Climate Change 2007, The Physical Science Basis, Contribution of Working Group I to the Fourth Assessment Report of the Intergovernmental Panel on Climate Change, Cambridge Univ. Press, Cambridge, UK, and New York, NY, USA, 2007.

Guenther, A., Hewitt, C. N., Ericson, D., Fall, R., Geron, C., Graedel, T., Harley, P., Klinger, R., Lerdau, M., McKay, W. A., Pierce, T., Scholes, R., Steinbrecher, R., Tallamraju, R., Taylor, J., and Zimmerman, P.: A model of natural volatile organic compound emissions, J. Geophys. Res., 100, 8873-8892, 1995.

Halmer, M. M., Schmincke, H. U., and Graf, H. F.: The annual volcanic gas input into the atmosphere, in particular into the stratosphere: A global data set for the past 100 years, J. Volcanol Geoth. Res., 115, 511-528, doi:10.1016/S0377-0273(01)003183, 2002.

Hegg, D. A.: Impact of gas-phase $\mathrm{HNO}_{3}$ and $\mathrm{NH}_{3}$ on microphysical processes in atmospheric clouds, Geophys. Res. Lett., 27, 22012204, doi:10.1029/1999GL011252, 2000.

Henin, S., Petit, Y., Rohwetter, P., Stelmaszczyk, K., Hao, Z., Nakaema, W., Vogel, A., Pohl, T., Schneider, F., Kasparian, J., Weber, K., Wöste, L., and Wolf, J.-P.: Field measurements suggest the mechanism of laser-assisted water condensation, Nat. Commun., 2, 456, doi:10.1038/ncomms1462, 2011.

Horowitz, L., Walters, S., Mauzerall, D., Emmons, L., Rasch, P., Granier, C., Tie, X., Lamarque, J., Schultz, M., Tyndall, G., Orlando, J., and Brasseur, G.: A global simulation of tropospheric ozone and related tracers: Description and evaluation of MOZART, version 2, J. Geophys. Res. D: Atmos., 108, ACH 161-ACH 16-25, 2003.

Kettle, A. and Andreae, M.: Flux of the dimethylsulfide from the oceans: A comparison of updated data sets and flux models, J. Geophys. Res., 105, 26793-26808, doi:10.1029/2000JD900252, 2000.

Kulmala, M., Laaksonen, A., Korhonen, P., Vesala, T., Ahonen, T., and Barrett, J. C.: The effect of atmospheric nitric acid vapor on CCN activation, J. Geophys. Res., 98, 22949-22958, 1993.

Kulmala, M., Korhonen, P., Laaksonen, A., and Vesala, T.: Changes in cloud properties due to $\mathrm{NO}_{\mathrm{x}}$ emissions, Geophys. Res. Lett., 22, 239-242, 1995.

Kulmala, M., Laaksonen, A., Charlson, R. J., and Korhonen, P.: Clouds without supersaturation, Nature, 338, 336-337, 1997.

Laaksonen, A., Korhonen, P., Kulmala, M., and Charlson, R.: Modification of the Köhler Equation to Include Soluble Trace Gases and Slightly Soluble Substance, J. Atmos. Sci., 55, 853-862, 
1998.

Lamarque, J.-F., Kyle, G., Meinshausen, M., Riahi, K., Smith, S., van Vuuren, D., Conley, A., and Vitt, F.: Global and regional evolution of short-lived radiatively-active gases and aerosols in the Representative Concentration Pathways, Clim. Change, 109, 191-212, doi:10.1007/s10584-011-0155-0, 2011.

Liao, H., Seinfeld, J., Adams, P., and Mickley, L.: Global radiative forcing of coupled tropospheric ozone and aerosols in a unified general circulation model, J. Geophys. Res. D: Atmos., 109, D16207 1-33, doi:10.1029/2003JD004456, 2004.

Lohmann, U. and Feichter, J.: Global indirect aerosol effects: a review, Atmos. Chem. Phys., 5, 715-737, doi:10.5194/acp-5-7152005, 2005.

Lohmann, U., Stier, P., Hoose, C., Ferrachat, S., Kloster, S., Roeckner, E., and Zhang, J.: Cloud microphysics and aerosol indirect effects in the global climate model ECHAM5-HAM, Atmos. Chem. Phys., 7, 3425-3446, doi:10.5194/acp-7-3425-2007, 2007.

Lu, Z., Streets, D. G., Zhang, Q., Wang, S., Carmichael, G. R., Cheng, Y. F., Wei, C., Chin, M., Diehl, T., and Tan, Q.: Sulfur dioxide emissions in China and sulfur trends in East Asia since 2000, Atmos. Chem. Phys., 10, 6311-6331, doi:10.5194/acp-106311-2010, 2010.

Ma, J., Chen, Y., Wang, W. Yan, P., Liu, H., Yang, S., Hu, Z., and Lelieveld, J.: Strong air pollution causes widespread haze-clouds over China, J. Geophys. Res., 115, D18204, doi:10.1029/2009JD013065, 2010.

Makkonen, R., Asmi, A., Kerminen, V.-M., Boy, M., Arneth, A., Hari, P., and Kulmala, M.: Air pollution control and decreasing new particle formation lead to strong climate warming, Atmos. Chem. Phys., 12, 1515-1524, doi:10.5194/acp-12-15152012, 2012.

Moss, R. H., Edmonds, J. A., Hibbard, K. A., Manning, M. R., Rose, S. K., van Vuuren, D. P., Carter, T. R., Emori, S., Kainuma, M., Kram, T., Meehl, G. A., Mitchell, J. F. B., Nakicenovic, N., Riahi, K., Smith, S. J., Stouffer, R. J., Thomson, A. M., Weyant, J. P., and Wilbanks, T. J.: The next generation of scenarios for climate change research and assessment, Nature, 463, 747-756, doi:10.1038/nature08823, 2010.

Nenes, A., Charlson, R. J., Facchini, M. C., Kulmala, M., Laaksonen, A., and Seinfeld, J. H.: Can chemical effects on cloud droplet number rival the first indirect effect, Geophys. Res. Lett., 29, 1848, doi:10.1029/2002GL015295, 2002.

Rast, S. et al.: Evaluation of the tropospheric chemistry general circulation model ECHAM5-MOZ and its application to the analysis of the chemical composition of the troposphere for the period 1960-2000 (RETRO), Max Plank Institute report, No. 114, Hamburg, Germany, 2012.

Riahi, K., Gruebler, A., and Nakicenovic, N.: Scenarios of longterm socio-economic and environmental development under climate stabilization, Technol. Forecast. Soc., 74, 887-935, doi:10.1016/j.techfore.2006.05.026, 2007.

Romakkaniemi, S., Kokkola, H., and Laaksonen, A.: Parameterization of the nitric acid effect on CCN activation, Atmos. Chem. Phys., 5, 879-885, doi:10.5194/acp-5-879-2005, 2005a.

Romakkaniemi, S., Kokkola, H., and Laaksonen, A.: The soluble trace gas effect on $\mathrm{CCN}$ activation: infuence of initial equilibration on cloud model results. J. Geophys. Res. 110, D15202, doi:10.1029/2004JD005364, 2005b.
Rotstayn, L. and Penner, J.: Indirect aerosol forcing, quasi forcing, and climate response, J. Climate, 14, 2960-2975, 2001.

Schulz, M., de Leeuw, G., and Balkanski, Y.: Sea-salt aerosol source functions and emissions, in Emission of Atmospheric Trace Compounds, 333-359, 2004.

Small, J. D., Chuang, P. Y., Feingold, G., and Jiang, H.: Can aerosol decrease cloud lifetime?, Geophys. Res. Lett., 36, L16806, doi:10.1029/2009GL038888, 2009.

Smith, S. J., van Aardenne, J., Klimont, Z., Andres, R. J., Volke, A., and Delgado Arias, S.: Anthropogenic sulfur dioxide emissions: 1850-2005, Atmos. Chem. Phys., 11, 1101-1116, doi:10.5194/acp-11-1101-2011, 2011.

Stier, P. et al.: Mechanistic Aerosol-Cloud Coupling and Indirect Aerosol Effects in the aerosol-climate model ECHAM-HAM, in preparation, 2012.

Tegen, I., Harrison, S. P., Kohfeld, K., Prentice, I. C., Coe, M., and Heimann, M.: Impact of vegetation and preferential source areas on global dust aerosol: Results from a model study, J. Geophys. Res., 107, 4576, doi:10.1029/2001JD000963, 2002.

Topping, D. O. and McFiggans, G.: Tight coupling of particle size, number and composition in atmospheric cloud droplet activation, Atmos. Chem. Phys., 12, 3253-3260, doi:10.5194/acp-12-32532012, 2012.

Twomey, S.: The influence of pollution on the shortwave albedo of clouds, J. Atmos. Sci., 34, 1149-1152, 1977.

van Vuuren, D. P., den Elzen, M. G. J., Lucas, P. L., Eickhout, B., Strengers, B. J., van Ruijven, B., and Wonink, S. van Houdt, R.: Stabilizing greenhouse gas concentrations at low levels: an assessment of reduction strategies and costs, Clim. Change, 81, 119-159, doi:10.1007/s/10584-006-9172-9, 2007.

Vehkamäki, H., Kulmala, M., Napari, I., Lehtinen, K. E. J., Timmreck, C., Noppel, M., and Laaksonen, A.: An improved parameterization for sulfuric acid/water nucleation rates for tropospheric and stratospheric conditions, J. Geophys. Res., 107, 4622-4631, 2002.

Vignati, E., Wilson, J., and Stier, P.: M7: An efficient size-resolved aerosol microphysics module for large-scale aerosol transport models, J. Geophys. Res., 109, D22202, doi:10.1029/2003JD004485, 2004.

Wespes, C., Hurtmans, D., Herbin, H., Barret, B., Turquety, S., Hadji-Lazaro, J., Clerbaux, C., and Coheur, P.-F.: First global distributions of nitric acid in the troposphere and the stratosphere derived from infrared satellite measurements, J. Geophys. Res., 112, D13311, doi:10.1029/2006JD008202, 2007.

Xu, L. and Penner, J. E.: Global simulations of nitrate and ammonium aerosols and their radiative effects, Atmos. Chem. Phys. Discuss., 12, 10115-10179, doi:10.5194/acpd-12-10115-2012, 2012.

Xue, H. and Feingold, G.: A modeling study of the effect of nitric acid on cloud properties, J. Geophys. Res., 109, D18204, doi:10.1029/2004JD004750, 2004.

Zhang, K., O’Donnell, D., Kazil, J., Stier, P., Kinne, S., Lohmann, U., Ferrachat, S., Croft, B., Quaas, J., Wan, H., Rast, S., and Feichter, J.: The global aerosol-climate model ECHAMHAM, version 2: sensitivity to improvements in process representations, Atmos. Chem. Phys. Discuss., 12, 7545-7615, doi:10.5194/acpd-12-7545-2012, 2012. 